\section{Online emergency resources}

Heritage Preservation's Heritage Emergency National Task Force has redesigned its Web pages to improve access to emergency resources. Links are organized to be used either pre- or post-disaster, and many of the resources are free.

Resources for Emergency Planning and Preparedness are subdivided into eight categories: Know Your Risks, Plan for Collections Emergencies, Prepare an Historic Property for Emergencies, Learn What Funding is Available and How to Get It, Train Your Staff and Volunteers, Get to Know Your Emergency Responders, Make a Case for Emergency Preparedness, and Protect Family Treasures from Disaster. Resources for Response and Recovery are subdivided into nine categories: Respond to and Emergency, Get Professional Help, Assess Damage, Get Funding to Aid Your Recovery, Share Information with Your Community and Local Media, Protect Your Health, Salvage Your Collections, Salvage an Historic Property, and Salvage Family Treasures from Disaster. The Web site also includes information about recent major disasters and Task Force activities.

The URL is www.heritagepreservation. org/programs/TASKFER.HTM.

\section{ARL preservation report}

The Association of Research Libraries (ARL) has released Safeguarding Collections at the Dawn of the 21st Century: Describing Roles and Measuring Contemporary Preservation Activities in ARL Libraries by Lars Meyer. It provides an overview of a number of preservation functions currently performed in research libraries and suggests how they should be characterized and measured. Meyer considers reshaping those functions by examining the creation of digital surro-

Jane Hedberg is senior preservation program officer at Harvard University Library, e-mail: jane hedberg@harvard.edu; fax: (617) 496-8344 gates, the collection of Web-based content and machine-dependent media, and the conduct of traditional core activities.

He also looks at the networked digital environment and possibilities for interinstitutional collaboration in digitization, Web archiving, shared collection storage, and deacidification.

The report is available free of charge at www.arl.org/bm doc/safeguarding -collections.pdf.

\section{CCI technical bulletin}

The Canadian Conservation Institute (CCI) has published technical bulletin no. 29, Combatting Pests of Cultural Property by Tom Strang and Rika Kigawa. The 44-page leaflet reviews common types of pests that attack collections, presents a survey method to identify and gauge the severity of an infestation, and suggests Integrated Pest Management (IPM) remediation activities for coping with an infestation.

Technical bulletin 29 costs $\$ 20$ (CAD) in Canada and \$25 (CAD) in the United States and other countries. It is available from the CCI online bookstore at https://www.cci-icc. gc.ca/bookstore/viewCategory-e.cfm?id=18. ISBN: 798-0-660-19899-6.

\section{DLF merges into CLIR}

The Digital Library Federation (DLF) became a program of the Council on Library and Information Resources (CLIR) on July 1, 2009. DLF was founded in 1995 as a CLIR project and only became an independent organization in 2005.

The return to its former home was prompted by a desire to broaden its agenda, expand its contact with diverse groups of stakeholders, and take advantage of operational savings during difficult economic times. Initially, current DLF members will become charter sponsors of the new DLF. This will be separate from CLIR sponsorship and some organizations may hold both. $n$ 